\title{
The Community College in Comparative and Historical Perspective: The Development of the College Concept in British Columbia
}

\author{
JOHN D. DENNISON*
}

\begin{abstract}
The paper is concerned with an examination of one alternative model for post-compulsory education, the community college, as it has developed in British Columbia. Attention is given to the social and historical context in which the college idea developed, the forces which lead to its establishment and the particular form of institution which emerged.

Data, produced from research studies, are presented to indicate the extent to which the college has attained some of its objectives. The paper concludes with a discussion of the major problems and issues which the community colleges must face in the future. Wherever appropriate, comparisons are made with traditional systems of post compulsory education.
\end{abstract}

\section{RÉSUMÉ}

Le Collège communautaire vu d'une perspective comparée et historique

Le développement du concept des collèges en Colombie-Britannique

Dans cette étude, il s'agit d'un modèle alternatif de formation après la scolarité obligatoire, le collège communautaire, tel que celui-ci a été mis en valeur en Colombie-Britannique.

$L$ 'auteur porte son attention sur (a) le contexte social et historique dans lequel l'idée du collège a été développée, (b) les efforts qui ont mené à la mise sur pied des collèges et (c) la structure unique d'institution qui s'est dégagée.

L'auteur présente des données de mémoires le recherche pour indiquer jusqu'à quel point le collège a atteint certains de sea objectifs. L'étude se ter ine par une discussion des problèmes et questions majeurs anxquels collèges communautaires doivent faire face à l'avenir. 


\section{Introduction}

British Columbia, the most westerly of the ten provinces of Canada, is also one of the most wealthy in terms of natural and human resources. The population has grown at a rate in excess of the national average. In 1921, the population of British Columbia was 524,000 ; by 1951 it had reached 1,200,000; and by 1976, 2,600,000. A combination of high birth rates after the second World War and increasing migration, has produced a 16 per cent increase in population between 1966-1971. (1) The economy of the province is largely natural resource based, while the relatively limited growth of secondary industry has stimulated continuing concern in political and economic circles.

With respect to the emphasis placed upon tertiary education (5), British Columbia has experienced a remarkable decade of development from 1965-1975. Prior to that period, progress had been extremely modest. The University of British Columbia was established in 1915 and, in keeping with other Canadian universities, had chartered a somewhat conservative course of development. Enrollment had grown slowly, reaching just over 3000 by 1945 , and following a brief period of expansion when war veterans flocked to the campus during 1947-1948, continued to grow at a gradual rate until 1953 when the enrollment had reached just over 5000 .

The university had established one satellite college (6) in Victoria, the capital city, and these two campuses, in addition to one small private college (7) represented the entire spectrum of post secondary education in British Columbia until 1965. It should also be noted that a number of post-secondary level vocational schools had been constructed throughout the province by the Ministry of Education. As their name implies, these schools were narrow in scope and generally not regarded as institutions of tertiary education. opportunities were offered, however, in a number of high schools throughout the province for students to complete Grade 13 one year beyond the high school diploma. By doing so, a student could accumulate a limited number of academic credits for transfer towards a degree at the University of British Columbia.

As suggested earlier, the 1968-1978 decade produced a notable growth in the number and kinds of tertiary educational institutions located throughout the province. By 1978, a student graduating from a British Columbia secondary school was confronted with a choice of three public universities, an institute of technology, fourteen community colleges, two private colleges and six "provincial institutes," designed for a variety of specific purposes.

The complex set of circumstances that lead to this unprecedented growth of educational institutions in British Columbia, the reasons for the types of institutions which developed and form of governing structure for their operation will be addressed in detail in the remainder of this paper.

\section{The Development of Post-Secondary Education in British Columbia}

Prior to 1962 , neither the University, nor society at large, had shown any particular interest in the development of other institutions of post-secondary education. The University was content to grow gradually and support its single affiliated college. There were several reasons for this complacency. University presidents, who had consumed considerable energy in a continuing battle with the provincial government for adequate financial support, saw in the growth of alternative institutions yet a further drain on the educational dollar. 
Further, as there seemed to be no great surge in expressed need for educational opportunity from the citizens of the province, the university was the logical site for a highly centralized campus with gradual growth of faculties and schools. The public had been generally suspicious of non-university institutions, assuming them to hold academic standards of varying quality, Occasional attention in the public press to such institutions in the United States helped to sustain this view.

However, certain demographic and economic facts in North America had emerged. The size of the college age population was growing rapidly. In addition, the percentage of this population seeking higher education was increasing at a similar rate. In British Columbia, this figure had reached 18 per cent by 1961 , as compared to 12 per cent in Canada and 40 per cent in the United States. (8) Projections suggested an equivalent figure of 25 per cent in British Columbia by 1971. (9) It was clear that UBC was contemplating an enrollment of 30,000 by 1970 - an undersirable figure in the view of most academics. Even to the most conservative of University adminstrators, it was evident that action had to be taken.

Several courses of action were open. The University of British Columbia could expand dramatically. A number of "branch colleges" could be established throughout the province, or a system of diversified tertiary educational institutions could be developed. The first alterative was unacceptable. The second seemed at least to ensure quality standards and, in fact, the government had provided for such an eventuality by amending the Public Schools Act to allow for school boards to plan colleges under "affiliation" with UBC. (10) However, it was the third alternative which came to fruition, in large part as a result of an important event - the appointment in 1962 of John B. Macdonald as President of the University of British Columbia.

Macdonald was a man of remarkable energy, foresight and determination. Coming from a research position at Harvard University, he immediately announced his intention to make a study of the long term needs in post-secondary education for the province of British Columbia. Macdonald drew together a group of faculty and began a tour of the interior to hear first hand the aspirations of the people of the province.

It became clear to the Macdonald Committee that limited accessibility to post-secondary education was a fact. The limitations were geographic, socio-economic, cultural and academic. The University, located in the city of Vancouver, was clearly an unsuitably goal for many young people of college age.

Among those who were most active in presenting briefs to the committee were the Boards of School Trustees who were responsible for administering public education at the local level. The trustees' position on colleges was clear and unequivocal:

Boards of School Trustees should be responsible for meeting all educational needs in a community which may reflect the needs of the community for adults as well as children, in academic and vocational fields alike, including the development and operation of community colleges, which properly are extensions of the public school programme of a community. (11)

Further, the brief from the B.C. School Trustee Association drew attention to the existence of vocational school and viewed their establishment "with alarm" as "entities separate from the school system, and which look upon various technical, commercial, etc., activities and programs as being quite apart from general schooling." (12) 


\section{John D. Dennison}

The University Senate presented its own brief (13) and, in doing so, reviewed several arguments used in the past regarding diversification of higher education. While the brief noted that those seeking higher education would increase, it rejected a plan either to enlarge UBC or to construct more universities. On the other hand, it recommended the development of a differentiated system of higher education throughout the province, to include institutions which would be academically autonomous and multipurpose in curricular design.

In doing so, the brief stated that:

Many people feel that a system of differing institutions is basically undemocratic, will give rise to feelings of discrimination, will deepen feelings of calss consciousness and resentment, because such a system necessarily makes distinctions between student interests and abilities, and tailors education accordingly.

English experience is often cited in this regard; however, we do not find it relevant. If there are problems of this sort in England they seem traceable largely to education at the lower level, not under discussion here, and in any case Western Canada does not begin with a class heritage even remotely analogous to England's. (14)

The final report (15) of the Macdonald Committee drew attention to many problems already stated. It also noted the demand for trained manpower in a resource based economy and made reference to the need to provide higher education for all those who could benefit from such an experience. Macdonald recommended the establishment of two four-year universities and a number of local, multipurpose colleges offering programs of two years duration and autonomous in function and governance.

In particular, the two year colleges were to develop under the auspices of the local school boards, with local financial support up to one third of their operating cost. Programs were to include university transfer and technical programs tailored to local needs.

Public reaction to the report was enthusiastic and positive. The prestige of a university president was undeniable and the arguments made for diversification and local control were convincing. The government acted with unaccustomed speed and the legislation required to enact Macdonald's recommendations followed in a matter of months. (16)

In general, the Macdonald Report coincided with the government's attitude to postsecondary education. The onus for development was placed upon the local authorities and only after a plebiscite, to approve the idea of a college, and a referendum to agree to support it financially, would the government act in establishing the college. The financial formula for the operating and capital costs included fifty per cent from local sources and fifty per cent from the government. In view of the fact that considerable federal money, in direct and indirect form, was provided for college programs, the provincial government was in an enviable position.

Given the permissive, rather than the prescriptive, nature of the legislation it was not surprising that the more wealthy and more progressive communities within a province took advantage of the opportunity and initiated the required procedures for establishing a college. Plebiscites were successfully concluded in Vancouver city and in the West Kootenay region. However, in the subsequent referenda, Vancouver voters rejected the money by-law required to authorize capital expenditure, while the West Kootenay voters gave their assent. The latter proved to be an extraordinary decision, as all subsequent referenda, held in a large variety of communities throughout the province, were unsuccess- 
ful. Based on these events, one rather ambiguous conclusion could be drawn. British Columbia voters, while supportive of college development in their communities, were reluctant to commit funds for their construction.

Despite the foregoing, community groups and School Boards in a number of regions were able to chart a notably pragmatic alternative to capital development. Colleges were opened, at odd hours, either in high schools or in leased facilities, operating funds were drawn from school district budgets and students enrolled in encouraging numbers.

By 1973, ten community colleges were in operation and their success seemed assured. Clearly, citizens in most larger communities saw a need for educational opportunities at the post-secondary level and responded to the opportunity which the legislation had provided. The availability of two years of university level education, without the expense and trauma of moving to the coastal universities proved to be an attraction for large numbers of citizens, both college age and adult. A local college had almost become a necessity for progressive communities in a potentially wealthy province.

By 1974, however, the boom period of educational expansion was all but over. Economic difficulties forced post-secondary education from high public priority. The new government, committed to the colleges as instruments of the democratization of higher education, established a task force to prepare a long term plan for future college development. The task force emphasized the need for college facilities in every region of the province if equality of educational opportunity was to be realized. In recognition of the changing educational climate, the government took the initiative and, without requiring the legislated action, established four more colleges in regions not served by such institutions to that time.

In 1975 the government changed again but reaffirmed support for the community college system. After two reports had been commissioned, one on continuing education and another on technical and trades training, the long awaited College Act (Bill 82) was tabled in the legislature. The Act outlined a new format for organization of the college system, guaranteed provincial funding for total operating expenses and provided for the establishment of provincial "institutes", these being single purpose institutions within the college system. Before another year had passed the latter category allowed for the designation of the Open Learning Institute, a provincial art school, the Pacific Vocational Institute, the Marine Training College and a Justice Institute.

It might be argued that single purpose institutions are clearly in conflict with the idea of the comprehensive community college. In fact, their establishment reflects a response to a particular type of pressure from certain educational groups to retain a specificity of purpose in the design of their institutions. Further comment on this arrangement will be made in the latter part of this paper.

By 1978, a grand total of twenty institutions of non-university post-secondary education in the province had been established. By any criterion, this fact represented fourteen years of remarkable growth and commitment to tertiary education. The progress had been unabated, despite two changes of governments with conflicting political philosophies, deteriorating economic conditions and changing public attitudes to education.

The underlying reasons for such progress were many and complex. Part of the explanation must be attributed to the political advantage which governments accrued from supporting college development. The community college, by its design, represents an attractive alternative to the universities, the latter long being regarded by the general public as bastions 
of the elite. Furthermore, the sixties was a period of extraordinary public sympathy for tertiary education and, coincidental with the release of Macdonald's imaginative report, established a climate for growth which had never before been equalled.

It is appropriate at this stage to examine the community college, as both an ideal and a practical concept. As with many such educational enterprises, rhetoric is often far removed from reality.

\section{The Community College Concept in British Columbia}

The community college is generally regarded as a uniquely North American contribution to the design of post-secondary education. The founding of the first public "junior" college in the United States in 1901 (17) led to a long period of development where the college has undergone a dramatic evolutionary process. Indeed, one of the college's features is its flexibility in being able to adjust its modus operandi to meet the particular social and political context in which it exists. The varying design of the college in eight of Canada's provinces and fifty U.S. states is testimony to this fact.

The college concept in British Columbia is characterized by certain features which are consistent with the basic features of the college in other jurisdictions. (18)

The college is designed to respond to its local community. Curriculum patterns are planned to meet the expectations and goals of a commuting student population. The college is administered by a relatively autonomous College Board, whose membership includes a large representation of local citizens. Local expertise found in the community is utilized by the college in developing programs and courses.

The community emphasis is best reflected in the wide differences which exist among colleges, even in the same city. The flexibility in design and structure not only allows for this phenomenon to occur but actually encourages it.

The community college is designed to be a "democratizing" force (19) in post-secondary education. Every effort is made to ensure that the large segment of the population, previ-. ously excluded from university education, is encouraged to enroll in the community college. As stated earlier, inaccessibility to tertiary education in the past has been based in socioeconomic, geographic, academic and cultural factors. The colleges have met these problems by providing for "open admissions," a fee structure considerably less than the universities, an organizational plan which provides for course attendance by day or evening, by part or full time study and a counselling service which attempts to meet student problems with a broad approach - be these problems academic or psychological.

It should be noted that the open admissions policy provides for college entrance for all students of post-secondary school age, irrespective of previous academic accomplishment. However, the open door does not mean that to all students. Rather, the obligation is upon the college to provide educational experiences in the form of basic skills or remedial courses to allow a student to correct his educational deficiencies before embarking on the program of his choice.

Although originally designed for "college-age" students, the college, largely as a result of the initiatives stated above, has attracted a population over half of which are "mature" in terms of age. (20) 
Furthermore, the colleges have attempted to meet the needs of quite geographically diverse populations by developing satellite or branch campuses where the numbers of potential students are viable.

The comprehensive college curriculum has been a constant challenge to employ in practice. "Comprehensive," suggests a multipurpose approach to curriculum and the ideal has been to offer all programs and courses which involve study at the post-compulsory level. Programs include "university transfer," in which a student may earn up to two years of credit on most university degrees. Para-professional, technical or career programs, up to two years in length, are offered which are designed to lead to immediate employment. The vocational schools have been melded with the colleges so that a variety of short term programs in skilled trades, often sponsored by the federal department of Manpower, are available in the college. A wide selection of continuing education courses of a credit or non-credit, recreational, cultural or upgrading are included within the college curriculum. In effect, all programs, other than those peculiar to a university, are to be found in the community college.

The multipurpose design allows for student mobility among its various programs. Students may change educational goals where such change is indicated - a problem which many young people face. Students on vocational programs may take advantage of general education courses and considerable "mixing" occurs within instructional groups.

This sociological "mix" which comprises the population in a college is worthy of comment. Students range widely in age, in years away from formal education, in ideals, hopes and aspirations for the future. (21) The understandings and appreciations which grow from constant informal contacts among these students are, in their own way, as important as the formal learning taking place in classrooms, workshops and laboratories.

Finally, the colleges are dedicated to teaching in terms of faculty responsibilities. Faculty are selected primarily on their teaching skills. The colleges seek faculty - student contact by ensuring reasonable class sizes and encouraging the counselling function as a faculty responsibility. For many students the college is an important transition between school and university and an opportunity to develop independent and mature study skills.

With particular reference to British Columbia, the community college has attempted to meet the ideals described above. The requirement for a local financial contribution to the operating costs has generally ensured community involvement, but increasingly, the ideals are becoming more difficult to attain.

There are many models for the governance of the college system within a state or provincial jurisdication. The Master Plan in California involves a systematic organization of higher education into which the universities, state colleges and community colleges are coordinated. Other systems provide for only one governing body for post-secondary education. In British Columbia, the universities and the colleges operate under independent councils at the provincial level. In such a form of organization there is potential for duplit: cation and competition for programs, facilities and other resources. Traditionally, autonomy is a much desired quality for institutions of higher education and any form of provincial structure is perceived as a threat to such autonomy.

It would seem useful to examine in a brief analysis, the extent to which the colleges have met their objectives over the first decade. Certain empirical data are available and will be summarized in the next part of the paper. 


\section{Some Data on the College System}

In 1975 a four year study was completed which examined the impact of the community colleges in British Columbia. (22) The project had focussed upon the entire post-secondary system, the students as part of the system and the views of the community at large. Eventually, the impact of the colleges within these areas became reasonably clear.

In terms of socio-economic factors, characteristics studied included parents' occupation, education and family income. It was evident that colleges were attracting a much wider population, in socio-economic terms, than had previously attended the university. However, college students, as a group, were still a select population, while university students were considerably more select. For example, while 25 per cent of university students had fathers with first degrees or higher, the corresponding figure for college students was 13 per cent. Family incomes, when summarized into the two categories "over $\$ 10,000$ per year" and "under $\$ 10,000$ per year" showed that the percentages for college students was 35 percent and 20 per cent, respectively. For university students, the corresponding figures were 44 per cent and 18 per cent. (23)

As a matter of interest the following table is presented to display a comparative summary of one aspect of socio-economic status, namely "father's occupation."

TABLE 1

Percentage of Students by Father's Occupation

\begin{tabular}{lcc}
\hline & $\begin{array}{c}\text { Father's } \\
\text { Managerial }\end{array}$ & $\begin{array}{c}\text { Occupation } \\
\text { Professional }\end{array}$ \\
\hline College Students & 20.8 & 10.6 \\
University Students & 25.4 & 19.5 \\
Vocational School Students & 6.4 & 4.0 \\
Grade 12 Students & 18.9 & 9.5 \\
Population of British & 11.8 & 7.9 \\
\hline
\end{tabular}

*Based on 1961 Census.

When academic achievement was examined, it was clear that college students, as a group , were extremely heterogeneous. Many were long removed from formal education, had modest academic records and held diverse educational goals. For many college students, theirs was a first venture into post-compulsory education in their respective families. Many students expressed a tentative, undecided view of their future educational aspirations and apparently regarded the college as a place to test their intellectual resources.

A series of "follow-up students" were also completed involving those students who had transferred to university after an initial one or two years at the college. The great majority of these students lost no academic credit in the transfer process and experienced minimal difficulty in doing so.

At university, college transfers seemed to attain reasonable success. While their record of first class marks is only fair, few students fail their year. The performance of transfer students tends to improve after the first year of transfer. "Borderline" students, those who earn less than a $\mathrm{C}+$ average at college, account for the greatest proportion of the unsuccessful performances at university. 
While there is a great variation in performance among colleges from which students transferred and also among the university faculties in which they enter, it must be emphasized that many of these students would have been denied university entrance had they not taken the college transfer route.

Finally, it was found that the colleges had not, to that stage, formed a clear identity with society at large. Employees and community groups were only beginning to recognize the role and nature of the college, despite ongoing efforts to gain public understanding. Apparently, the process of "identity building" is a long procedure.

Having given the current status of the colleges, the circumstances which surrounded their development and their measure of goal attainment, the final task in this paper will be to examine the future of the colleges. In doing so, the prime foci will be to examine the consequences of increasing financial demands of changing societal priorities and of rapidly changing student populations.

\section{The Future of the Community College}

While the future of the community colleges is somewhat clouded there are directions and emerging issues which are already apparent.

The costs of the total educational system, and the college component in particular, have been growing at a dramatic rate. The post-secondary educational share of the budget in British Columbia has increased from \$102.4 million in 1963 to $\$ 355$ million in 1978 . The government has responded to rising financial demands in a manner which is largely predictable. A new College Act (24) has been proclaimed which, while placing the financial costs of the colleges entirely within the provincial budget, has created a complex system of provincial authorities which will control college development. The fear has been expressed that the "community" emphasis within the college plan is destined to be replaced by a "provincial" focus. Colleges will find it more difficult to respond to local needs and local initiatives, as all programs will be "coordinated" through a provincial council. It will also become increasingly difficult for colleges to be innovative in program development. In highly centralized systems, individual college initiatives receive little consideration when policy is to be applied universally. The task of balancing costly duplication of programs with college priorities for community needs will require imagination and creativity.

Colleges, as is the case with most social institutions, are subject to the effects of changing political priorities. The current government view is that colleges are integral parts of the economic plan for development of the province and hence increasingly responsible for the training and production of skilled manpower. While the goal is a worthy one, the other curriculum areas of the traditionally comprehensive college are concerned. about their future. Those who support the notion of liberal or general education as major responsibilities of the college which contribute to the quality of life in the community, and those who emphasize the college's role in continuing education, feel little sympathy emanating from the Ministry of Education.

The ongoing debate with curricular priorities has produced two extreme views on the future of the colleges. Some suggest that academic education belongs properly in the universities and colleges should relinquish their university transfer programs. Colleges in other provinces supply precedents for this approach. On the other hand, other educators 
suggest that the universities should relocate all of their lower division courses in the colleges and concentrate on their responsibility for advanced study and research. While the majority of members of the educational community support neither extreme there is increasing concern expressed that either may occur.

Included within the new legislation is a provision for the establishment of "provincial institutes" (25), in addition to colleges. These institutes are generally single-purpose in curricular design and their creation appears to reflect a new government initiative in tertiary education. This new direction is away from comprehensive colleges and towards a clear separation of function. This approach involves the location of students and faculty into different institutions - a trend which, for good reason, has been rejected in the past. A strong case can still be made for comprehensive education, although, for a variety of reasons, the ideal has had limited success. The debate on the new government policy in this respect has only just commenced. The ideal of the truly comprehenisve curriculum, as developed earlier in this paper, will need strong and articulate advocates if it is to survive.

Another problem which is becoming more intensive is the consequence of a rapidly declining population of college age students. The public school system is giving attention to the trend and preparing various strategies for its solution. Of all post-secondary institutions, the college seems best equipped to meet the challenge. A variety of creative initiatives in terms of program development, directed at non-traditional sources, such as ethnic minority groups, retired and older citizens, the under-educated adult population and the unemployed segment of society, will be needed in the next decade. The college has the potential and the structure to adjust to rapid change. Whether it chooses to do so will depend upon the leadership which it enjoys.

Partly as a consequence of a steady state in enrollment, there is reduced mobility for teaching faculty in community colleges. Hiring of new full time college teachers has been greatly modified and the average age of continuing faculty is increasing rapidly. Much of the innovation in teaching techniques and program development is dependent upon faculty with current experience in the business, industrial and community areas. One trend which is already apparent is the increasing use of part-time faculty, a policy which produces a high degree of turnover. Another approach, largely untapped, is the extended use of professional development among full and part-time faculty. Although some use has been made of these programs, the challenge to make them effective in producing professional renewal and enthusiasm for innovation among college faculty has yet to be met.

One other problem concerning college teachers is the trend to unionization. Although the circumstances surrounding this trend is understandable, there are accompanying problems which seem inevitable. The notion of colleageality and the "community of scholars" are somewhat antithetical to the creation of bargaining units. The role of the faculty member in the internal governance of a college is not well understood by government officials or board trustees, while the union model does little to provide clarity.

Finally, one issue which the colleges have continued to face since their inception is the development of a clear identity. Students, faculty, government and the community at large are still confused as to whether the college is an autonomous component within the post-secondary system, an upward extension of the secondary school or a source of supply for the university or the work force.

There are many dimensions to the creation of a college identity. Legislation is necessary, 
the education of the public is mandatory, faculty, students, support staff and administration must develop pride in, and understanding of, the institutions in which they work and, above all, society in the broad sense must recognize and appreciate the role of the community college as a vital component in the educational future of the nation.

\section{A Final Comment}

The community college, perhaps more so than any other tertiary institution, may be regarded as a new structure in post-compulsory education. Although its roots extend over half a century, the college is in a constant state of renewal, in response to the changing needs of its clientele, the priorities of governments and the nature of the work force. The particular design of the college concept ensures its capacity for change. Above all else, this quality must endure if the college is to avoid the charge which has confronted so many social and educational institutions - the threat of redundancy!

The college is a child of the twentieth century - a century of unprecedented unheaval in social behavior and in alternative approaches to the design of the labor force. It may be argued that future shock will be so intense that even the college will be unable to respond. Only the passage of time will determine the validity of this charge.

Within the historical context in which it has developed, the community college has carved an exceptional record of achievement. Perhaps the success of the past will prove to be the impetus for the future.

\section{Notes and References}

1. The Canada Year Book, 1976, published by Statistics Canada.

2. British North American Act (1867), S. 93.

3. Particular examples of this point of view are J.A. Corry, "Higher Education in Federal - Provincial Relations", University Affairs, Vol. 8, no. 2. (Dec., 1966) and R.D. Michener, "A Footnote to Confederation: Why was University Education Made a Provincial Responsibility? C.A.U.T. Bulletin, Vol. 17, No. 2, (Dec. 1968).

4. For full discussion of this arrangement read S.G. Peitchinis, Financing Post Secondary Education in Canada, University of Calgary, 1971.

5. Throughout this paper the terms, "post-secondary," "higher," and "tertiary" are used interchangeably. "Post-compulsory," although not analogous, may be used as another equivalent term.

6. Victoria College - later the University of Victoria.

7. Trinity Western College.

8. Macdonald, John B., Higher Education in British Columbia and a Plan for the Future, University of British Columbia Press, 1962, (p. 8).

9. Op. cit. (p. 9).

10. The Province of British Columbia, Manual of School Law, Queen's Printer, 1958, Chap. 42., Sect. $17,(0)$.

11. British Columbia School Trustees Association, Brief to Macdonald Committee, Nov. 15, 1962 , p. 11.

12. Op cit., p. 5.

13. Senate of the University of British Columbia, "A Report of the Problem of Higher Education in British Columbia," 1962.

14. Op. cit., p. 17. 
40 John D. Dennison

15. Op cit.

16. Taped conversation with Dr. J.D. Chapman, Geography Department, U.B.C., a member of the Macdonald Committee.

17. Joliet Junior College, Illinois.

18. Community Colleges are to be found in Japan, Australia, Philippines, Mexico and the United States.

19. For further discussion of this idea read Jencks, C., and Riesman, D., The Academic Revolution, Doubleday and Company, Inc., New York, 1968.

20. Dennison, J.D., et al., The Impact of Community Colleges, B.C. Research, Vancouver, 1975.

21. Op. cit., Socioeconomic Background of College Students. (Chapter 5).

22. Op. cit.

23. Additional data on students at vocational schools and technical institutes are available.

24. The Province of British Columbia, Bill 82: Colleges and Provincial Institutes Act, Queen's Printer, 1977.

25. Op. cit. 